\title{
KERAGAMAN KEBERAGAMAAN (SEBUAH KODRATI KEHIDUPAN BERBANGSA DAN BERNEGARA BERDASARKAN PANCASILA)
}

\author{
Dewa Agung Gede Agung \\ Jurusan Sejarah, Universitas Negeri Malang
}

\begin{abstract}
Abstrak: Kehadiran berbagai agama di Indonesia merefleksikan agar umat beragama tidak saling menganiaya orang lain. Akan tetapi, agama yang mengajarkan perdamaian tidak jarang dijadikan legitimasi untuk mengganggu, memusuhi, dan memusnahkan umat lain. Di Indonesia, konflik antar umat beragama telah menjadi rahasia umum, dalam kondisi seperti ini ajaran agama dapat dijadikan sebagai alat pembenar bagi pemeluknya untuk melakukan tindakan permusuhan dan pembunuhan terhadap pemeluk agama lain. Kenyataan ini sangat bertentangan dengan esensi ajaran agama itu sendiri yang selalu mengajarkan cinta kasih dan perdamaian. Masyarakat Indonesia adalah masyarakat majemuk dengan pemeluk agama yang beragam. Belum lagi perbedaan suku dan ras, bisa jadi faktor ini juga berpotensi memperkeruh suasana konflik agama. Namun demikian, kemungkinan diatas bisa jadi tidak terbukti apabila masyarakat dan bangsa Indonesia mampu menumbuhkan sikap empati terhadap perbedaan tersebut.
\end{abstract}

Kata-kata Kunci: bangsa dan negara, empati, empat konsensus dasar

\begin{abstract}
The presence of religions in Indonesia reflects that the religious people do not violate each other. However, religion teaching peace is become a legitimation to disturb, to hate, and to genocide the other religious people. In Indonesia, a conflict between religions have been a public secret, in this condition the teaching of religion could be a tool to right and to legitimate the killing of other religions. This fact is contradicted with the essence of the religion's teaching that is to teach love other people and peace. Indonesian society is a multicultural society with various religions. Nevertheless, the related explanation will not affect if society could grow the character of emphaty to any difference.
\end{abstract}

Keywords: nation and state, emphaty, four basic consencus

Kekerasan atas nama agama sering mewarnai kehidupan manusia. Entah ia muncul sebagai akibat hubungan antarumat beragama yang tidak dibarengi sikap toleran, atau ia sengaja diciptakan untuk mendukung kepentingan kelompok tertentu. Jika ditelaah lebih dalam, sesungguhnya konflik antar agama lebih banyak disebabkan faktor ekonomi dan faktor politik, di samping juga adanya usaha sengaja dari kelompok yang ingin mempertahankan atau meraih status sosial yang lebih baik. Dan apabila konflik agama tidak diberikan perhatian serius dari semua pihak, maka bangsa Indonesia akan menghadapi persoalan besar, yakni disintegrasi bangsa dan carut marutnya NKRI.
Potensi konflik di Indonesia sangat tinggi, hal ini disebabkan karena sifat heteroginitas di berbagai sendi kehidupan. Kondisi semacam ini sangat disadari oleh semua pihak terutama para cendekiawan. Karena itu sebagai wujud sikap kekhawatiran dan kepedulian sehingga diupayakan adanya penyadaran sehingga konflik-konflik yang bersifat SARA tidak berkelanjutan. Try Sutrisno dalam "Dimensi Pertahanan Keamanan dari Integrasi Nasional". Tulisan ini menyoroti sebagai negara yang menjunjung tinggi Pancasila seharusnya juga nilainilai Pancasia sebagai pedoman kehidupan berbangsa dan bernegara, dan nilai-nilai Pancasila sebagai rujukan dalam mengatasi setiap masalah 
bangsa (Sutrisno T., 1996). Empat konsensus dasar merupakan struktur dan modalitas dalam kehidupan berbangsa dan bernegara. Keempat tersebut adalah Pancasila, Undang-Undang Dasar Tahun 1945 (UUD 1945), Negara Kesatuan Republik Indonesia (NKRI), dan Kebhinekaan). Tentu semua ini tidak bisa lepas dari sentuhan aktor/agen yang membuat struktur dan sekaligus mematuhi struktur sebagai pedoman hidup berbangsa dan bernegara.

Tulisan Masykuri Abdila dalam "Toleransi Beragama dalam Masyarakat Demokrasi dan Multikultural". Tulisan ini menekankan pada perlunya nilai-nilai toleransi yang menjadi kesepakatan semua pihak. Nilai-nilai toleransi tersebut adalah (1) toleransi antarpenganut suatu agama tertentu, (2) toleransi antarpenganut agama yang berbeda, dan (3) toleransi antarpenganut agama dengan pemerintah (Abdila, 2003). Dalam "Prinsip-Prinsip Universal Toleransi Antar Umat Agama", mengatakan bahwa prinsip-prinsip toleransi agama ini, yang merupakan bagian dari visi teologi atau akidah, telah dimiliki oleh setiap agama, maka sudah selayaknya jika setiap umat bergama turut serta aktif untuk memperjuangkan visi-visi toleransinya di khalayak masyarakat plural. Perbedaan umat manusia, baik dari sisi suku bangsa, warna kulit, bahasa, adat-istiadat, budaya, bahasa serta agama dan sebagainya, merupakan fitrah dan sunnatullah yang sudah menjadi ketetapan Tuhan. Landasan dasar pemikiran ini adalah firman Tuhan yang Maha Kuasa (Anonim, 2009).

\section{KERUKUNAN UMAT BERAGAMA}

Konsep awal yang harus difahami adalah tidak ada satupun agama di Indonesia yang kita kenal sampai sekarang berasal dari Indonesia. Semua agama, apakah agama Hindu, Buddha, Islam, Nasrani dan Konghuchu adalah berasal dari luar Indonesia, mungkin tidak terlalu berlebihan kalau dikatakan semua agama di Indonesia adalah "agama import" (Subagya, 1981:5). Namun demikian, semua itu diterima dan berkembang ka- rena dapat menyesuaikan diri dengan unsur-unsur lokal melalui proses akulturasi. Kedatangan berbagai agama di tanah air, bukan masuk dalam wilayah yang tidak mengenal sistem religi, melainkan sudah mengenalnya walaupun awalnya masih sederhana. Seperti kedatangan agama Hindu dan Buddha, masyarakat Indonesia sudah mengenal sistem kepercayaan animisme dan dinamisme, yang dikenal juga dengan nama agama tradisional. Hal ini dibuktikan dengan sudah dikenalnya nama sang pencipta di setiap daerah dengan nama yang berbeda-beda (Subagya, 1981: 66-68). Begitu juga dengan kedatangan agama Islam yang diperkirakan sejak abad VII pada masa kerajaan Sriwijaya. Kedatangan para pedagang Islam tersebut dalam wilayah yang penduduknya sudah mengenal agama Buddha. Sejak awal abad XVI yang ditandai dengan berdirinya kerajaan Demak merupakan puncak perkembangan agama Islam di tanah air. Peranan wali/sunan sangat penting dengan menggunakan media budaya setempat, seperti melalui wayang, gending-gending Jawa dsb, bahkan semua itu dilestarikan (Lombard, 2005:340-341). Jadi sekilas latar belakang sejarah tersebut menunjukkan, bahwa perkembangan agama apapun di Indonesia tidak diawali dengan konflik, tetapi melalui cara-cara damai dan beradab.

Menurut penulis, melihat latar belakang sejarah kedatangan agama-agama di Indonesia dilandasi oleh sifat empati. Kata "empati", itulah kata yang tepat, kalau melihat hubungan antar agama dan kepercayaan lokal. Karena kata ini mempunyai makna bukan sekedar mengakui adanya perbedaan agama dan kepercayaan, tetapi mau "menerima" perbedaan tersebut dalam kehidupan sehari-hari. Dengan demikian dapat dikatakan "empati" merupakan modalitas yang sudah dimiliki oleh bangsa melalui proses "historisasi". Modalitas yang empati tentu tidak akan muncul tiba-tiba, namun peranan aktor/agen sangat penting. Kalau di kehidupan kemudian terjadi konflik-konflik yang bersifat SARA, berarti terjadi "rigres" dalam kehidupan berbhineka. Sering kita mendengar "pengalaman adalah guru 
utama”. Sejarah adalah pengalaman suatu bangsa, seharusya diposisikan sebagai guru dalam berbangsa dan bernegara dalam kehidupan sekarang dan di masa yang akan datang.

Berbicara struktur, modalitas, dan pentingnya peranan aktor/agen akan mengingatkan pandangan Anthony Giddens dengan "teori strukturasi”. Menurut Martono, khusus posisi Giddens ada pada filsafat post-positivisme yang bersifat interpretatif (Martono, 2014: 72-73). Karena itu Giddens dengan teori strukturasinya mengatakan "teori strukturasi" didasarkan pada premis bahwa "dualisme" harus dikonseptualisasikan sebagai sebuah "dualitas", struktur adalah sarana, tetapi juga hasil atau produk individu (Giddens, 2010:xix). Teori Giddens, fokus kajiannya adalah tindakan sosial (social action), dan pengalaman hidup (life experience). Karena itu teori strukturasi Giddens termasuk dalam Teori Sosial Kritis yang menggambarkan hubungan antara struktur dan manusia, individu sebagai aktor (Agger, 2014:9). Seorang penganut filsafat post-positivism atau postmodenis harus berani melakukan "dekonstruksi" terhadap berbagai fenomena yang terjadi, begitu juga dengan berbagai isu-isu SARA yang sering muncul di media sosial yang terkadang hoax. Para postmodenis umumnya tidak suka dengan penyeragaman dan tidak suka pula pada pembatasan, tetapi akan lebih senang dengan dan menerima perbedaan, keberagaman (Lubis, 2014:15).

Sering kita dengar bahwa sekarang adalah masuk generasi " $Z$ ", karena itu dalam tatanan berpikir filsafat seharusnya mampu melakukan dekonstruksi terhadap cara berpikir positivism. Memang tidak mudah, seperti pengalaman Anderson, yang dia tuliskan dalam buku "hidup di luar tempurung", tetapi dia percaya bahwa pemikiran seorang akademisi pasti sudah melalui kerangka kerja intlektual. Lebih lanjut di tuliskan;

".....kaum akademisi begitu berkomitmen terhadap konsep-konsep "kekuatan sosial", "struktur kelembagaan", "ideologi", "tradisi", "tren demografi dan semacamnya. Mereka juga tidak kurang berkomitmen pada "penyebab" dan "dampak-dampak" kompleks yang diakibatkannya. Dalam kerangka kerja intlektual semacam ini, cuma sedikit ruang yang ada kebetulan...." (Anderson, 2016: 181).

Kehidupan dalam masyarakat akan damai, teratur (order), atau konflik, tidak teratur (disorder) sangat tergantung pada aktor/agen sebagai produsen struktur (pola, aturan) dalam masyarakat. Berdasarkan pandangan Weber terdapat tiga tipologi kepemimpinan yang berkembang dalam masyarakat, yaitu 1) otoritas tradisional (traditional authority), 2) otoritas kharismatik (charismatic authority), dan 3) otoritas legal/rasional (legal/rational authority) (Arisandi, 2015: 68-70). "Guru", sangat memenuhi ketiga tipe kepemimpinan tersebut di atas. Karena itu peranan guru sangat penting, baik buruknya kehidupan berbangsa dan bernegara sangat tergantung pada guru (selain Guru Swadhyaya).

Penulis sebagai orang yang beragama Hindu, percaya pada pentingnya perana guru, dan ini juga yang mengilhami apa yang seharusnya dilakukan sebagai seorang guru. Dalam Agama Hindu (mungkin terdapat juga dalam agama yang lain), terdapat keyakinan terhadap Catur Guru, yang berarti empat Guru yang harus dihormati di dalam mencari kesucian serta keutamaan hidup, termasuk keutamaan hidup dalam kehidupan berbangsa dan bernegara (Anonim, 2005). Keempat guru tersebut adalah:

Guru Rupaka adalah orangtua kita. Disebut guru Rupaka karena Beliau yang melahirkan, membesarkan, dari tidak ada menjadi ada. Orang tua kita sesungguhnya sangat besar jasanya bagi kita. Karena saking besarnya jasa orang tua rasanya seribu kali kelahiranpun belum bisa kita akan membayar hutang kepada orangtua. Guru Pengajian berarti guru yang telah memberikan pelajaran di sekolah. Termasuk Guru Pengajian adalah; Guru TK, Guru SD, Guru SMP, Guru SMA, Dosen, Kepala Sekolah, Rektor. Guru 
Pengajian mengajari kita cara membaca, menulis, berhitung dan lain-lain, baik dalam pendidikan formal maupun non formal. Guru Wisesa adalah Pemerintah. Disebut Guru Wisesa karena Guru itulah yang melayani, menciptakan ketentraman dan kesejahteraan masyarakat. Guru Swadhyaya adalah Tuhan Yang Mahaesa yang menciptakan segala isi dunia ini dengan penuh kasih sayang. Tuhan yang menciptakan keindahan alam, laut, sungai, gunung, bulan, bintang dan planetplanetnya.

Setiap agama mengandung suatu ajaran moral sebagai pegangan perilaku para penganutnya, meliputi dua macam aturan. Di satu pihak cukup banyak aturan mendetail dalam suatu agama bertalian dengan haram/halal, puasa/tarak, ibadat/ritual. Di pihak lain terdapat aturan etis lebih umum yang melampaui kepentingan suatu agama saja misalnya, larangan membunuh, berdusta, mencuri. Namun di bidang dogma sukar tercapai kesepakatan antar -agama di bidang moral. Ajaran moral suatu agama dianggap penting karena sumbernya ialah Tuhan dan mengungkapkan kehendak-Nya, diterima berdasarkan argumen iman. Tetapi nilai-nilai dan norma-norma moral etis tidak begitu saja atau dengan sendirinya (eksklusit) diterima karena argumen keagamaan saja. Ada pula argumen-argumen lebih umum untuk menerima aturan moral misalnya argumen rasional, yang melarang membunuh, berdusta, mencuri. Dalam filsafat moral justru diupayakan menggali argumen rasional untuk nilai dan norma etis suatu tindakan. Namun demikian hal itu tidak berarti bahwa dalam bidang etis tidak ada kaitan erat antara agama dengan kebudayaan (Sutrisno, 2001:13-18).

Kebudayaan juga merupakan sumber nilai dan norma-norma etis, tetapi dalam banyak hal kebudayan nyaris tidak dapat dilepaskan dari agama. Hubungan antara agama dan kebudayaan bersifat timbal balik. Hal itu berarti bahwa cara hidup memengaruhi keagamaan, sedang sikapsikap keagamaan memengaruhi cara hidup. Sesuatu yang dirasakan sebagai kepentingan mutlak dalam kehidupan, sangat erat pertaliannya dengan agama dan dipagari dengan sanksi-sanksi keagamaan.

Salah satu dasar keberadaan kebudayaan dengan agama adalah interaksi sosial sebagai bagian dari keseluruhan gaya hidup manusia. Maka kebudayaan bersifat sosial, meliputi cara hidup yang teratur, berdasarkan tradisi yang sama, dan ditentukan oleh lingkungan yang sama pula. Hubungan antara agama dan kebudayaan terletak pada cara yang sama bertalian dengan pandangan hidup yang sama, kaidah-kaidah cara hidup yang sama, dan ukuran-ukuran penilaian yang sama pula. Maka kebudayaan merupakan suatu kerukunan rohani yang kesatuannya tergantung pada kepercayaan yang sama dan cara-cara berpikir yang sama. Sementara itu agama rnerupakan faktor yang kreatif, dinamis, dan perangsang pemberi hidup masyarakat pendukung kebudayaan. Agama mempertahankan masyarakat dalam pola-pola kemasyarakatan yang tetap, misalnya nampak dalam keanekaragaman adat istiadat hidup kekeluargaan, suku, pernikahan yang berlatar belakang keagamaan dan terikat sanksi keagamaan dan kebudayaan.

Agama dalam praktek dibatasi dan dipengaruhi oleh kebudayaan. Maka perkembangan kebudayaan terbuka bagi perubahan-pembahan baik agama maupun kebudayaan itu sendiri. Setiap perubahan materiil pengganti hidup fisik akan memengaruhi corak kebudayaan, dan akan menghasilkan sikap religius yang baru pula. Demikian pula setiap perubahan mental pemberi wujud baru pada pandangan manusia terhadap realitas akan mengubah cara hidup dan menghasilkan bentuk kebudayaan yang baru pula. Perubahan-perubahan tersebut dipengaruhi oleh ide-ide politik baru, penemuan-penemuan ilmiah baru, doktrin-doktrin keagamaan baru. Ide-ide baru tersebutlah dapat menimbulkan pola pikir baru yang mengarah pada kerukunan (order) atau bahkan sebaliknya (disorder). Ide-ide baru tersebut akan mempertajam pertentangan antar pendukung agama dan kebudayaan yang sudah menjadi 
kesepakatan dalam hidup secara turun-temurun dengan yang ingin melakukan perubahan terhadap kesepakatan tersebut.

Abdul Rahman dan Khambali menulis, bahwa setiap penganut agama biasanya cenderung eksklusivitas dengan mengklaim bahwa agama mereka adalah satu-satunya agama yang benar (Rahman \& Kambali, 2013). Namun di lain pihak masih terdapat kelompok-kelompok keagamaan yang menentang sekularisme, libralisme, dan pluralisme. Perbedaan ideologi keagamaan inilah kemudian bisa menyebabkan munculnya konflik (Jellen, 2007:39). Begitu juga masalah mayoritas dan minoritas. Menurut Haerudin, bahwa pluralisme adalah paham, sikap terbaik untuk mengelola dan menyongsong anugerah keberagaman (pluralitas). Sebuah sikap yang berasal dari pandangan, bahwa manusia beragama dialah manusia yang mencintai Tuhan, sementara mustahil mencintai Tuhan tanpa mencintai ciptaanNya (Nurcholis \& M. Dja'far, 2014: xi).

Dalam komunitas minoritas konflik muncul dari upaya mengejar kepentingan yang berbeda, tujuan dan aspirasi oleh individu, dan atau kelompok. Walaupun sangat disadari, bahwa konflik bersifat alami, dan sebagai eksistensi kehidupan sosial, sehingga intoleransi, konflik dan perang adalah fenomena sosial yang tak terelakkan. Namun yang terpenting adalah bagaimana mencari solusi untuk mengakhiri konflik (Echikwomye, 2013:83). Kesadaran dan niat, etikad untuk bersatu merupakan kunci untuk hidup berdampingan sehingga memunculkan rasa kebangsaan yang sejati (Soekarno, 1965: 3-4). Ini artinya hendaknya mulai dari dalam diri sendiri (faktor internal), disamping adanya kebijakan-kebijakan pemerintah yang mengkondisikan (faktor eksternal) sehingga dapat memunculkan kesadaran untuk hidup bersama dalam keberagaman. Banyak cara yang dapat dilakukan dalam menyelesaikan masalah, semua itu sebuah pilihan dengan segala konsekuensinya. Dengan segala dinamika dan kompleksitas kehidupan dalam masyarakat, menurut Pruitt dan Rubin (Pruit \& Rubin, 2011: 56-59), terdapat lima strategi dasar dalam menyelesaikan konflik yaitu:

1. Contending (bertanding, bersaing), segala usaha untuk menyelesaikan konflik menurut kemauan seseorang tanpa memperdulikan pihak lain. Pihak-pihak yang menerapkan strategi ini tetap mempertahankan aspirasinya sendiri dan mencoba membujuk pihak lain untuk mengalah, termasuk diantaranya dengan mengeluarkan ancaman.

2. Problem Solving (pemecahan masalah), usaha mengidentifikasi masalah yang memisahkan kedua belah pihak dan mengembangkan serta mengarah pada sebuah solusi yang memuaskan kedua belah pihak. Cara ini dapat dilakukan dengan cara kompromi dan integratif. Kompromi adalah alternatif nyata yang berada di antara posisi yang lebih disukai oleh masing-masing pihak. Sedangkan integratif adalah rekonsiliasi kreatif atas kepentingan-kepentingan berdasar masing-masing pihak.

3. Yielding, (mengalah), dimana orang harus menurunkan aspirasinya sendiri, tidak berarti penyerah total, karena mengalah bukan berarti kalah.

4. Inaction (diam), adalah tindakan temporer yang tetap membuka kemungkinan bagi upaya menyelesaikan kontroversi.

5. Withdrawing (menarik diri), adalah sebagai upaya untuk menghindari pertengkaran dengan cara menghindarkan diri dari masalah yang dihadapi.

Di Indonesia kesadaran untuk hidup rukun antar warga negara yang berbeda, termasuk perbedaan agama hendaknya berpedoman pada nilai-nilai Pancasila. Faktor internal, hendaknya dikaitkan dengan tingkat kesadaran masyarakat akan pendidikan, seharusnya dibarengi juga dengan tingkat kesadaran akan "hakekat" dari kehidupan. Bahwa dunia ini adalah plural, dari berbagai segi apakah itu agama, suku, etnis, dan semua itu adalah kodrat yang tidak mungkin 
dapat diingkari. Karena itu prinsip, bahwa "berbeda adalah rahmat" sangat tepat dalam kehidupan ini. Sebagai pengejawantahan dari pernyataan tersebut hendaknya diikuti dengan cara berpikir dan berperilaku yang nyata dalam kehidupan sehari-hari. Seperti melihat baik atau tidaknya seseorang bukan dari agama yang dianutnya, tetapi dari perilaku mereka, masuk tidaknya seseorang ke sorga bukan dari agama yang dianutnya, tetapi dari amal dan perbuatan mereka di dunia. Semua agama di dunia ini mengajarkan hal-hal yang positif sebagai pedoman moral baik untuk kepentingan horizontal maupun vertikal. Yang tidak baik bukan agamanya, tetapi oknumnya karena kepentingan-kepetingan tertentu. Dalam kehidupan yang serba berbeda sebenarnya tidak cukup hanya penanaman sifat toleransi, tetapi ada yang lebih penting yaitu bersifat empati. Toleransi secara etimologis hanya bermakna mengakui adanya perbadaan, sedangkan empati mempunyai arti yang lebih dalam yaitu adanya unsur penerimaan akan perbedaan tersebut dalam kehidupan sehari-hari. Pandangan Jalal al-Din Rumi mungkin dapat menjadi pertimbangan yang melukiskan pandangan pluralisnya dengan menggunakan gambaran berikut;

"Meskipun ada bermacam-macam agama, tujuannya adalah satu. Apakah Anda tidak tahu bahwa ada banyak jalan menuju ka'bah?...Oleh karena itu apabila yang Anda pertimbangkan adalah jalannya maka sangat beraneka ragam dan sangat tidak terbatas jumlahnya; tetapi apabila yang Anda pertimbangkan adalah tujuannya, maka semuanya terarah hanya pada satu tujuan" (Munawar-Rachman, 2009).

Akhirnya dalam spirit kesatuan inilah, kita menghargai keberbedaan. Perbedaan agama-agama ini harus dikenal dan diolah lebih lanjut, karena perbedaan ini secara potensial bernilai dan penting bagi setiap orang beragama dalam memperkaya imannya. Dan tidak ada salahnya kalau ada pedoman yang universal, bahwa "Tuhan hanya satu tetapi orang bijak menyebut banyak nama", tentu dengan tidak mengurangi ketaatan terhadap agama yang dianutnya, dan tidak mengatakan agama orang lain lebih jelek dari agamanya. Setiap pemeluk agama hendaknya selalu berusaha mencari ayat-ayat yang bersumber dari kitab sucinya dengan menonjokan kesamaan-kesamaan yang ada, bukan hanya berbicara tentang sorga dan neraka, apalagi yang ditonjolkan perbedaannya saja. Jadi, mencapai surga bergantung pada bagaimana sikap dan perilaku kita, bagaimana kita memperlakukan orang lain (Ali, 2008).

Faktor eksternal, terkait dengan kebijakankebijakan pemerintah dalam bentuk peraturanperaturan atau perundang-undangan yang dikeluarkan. Sejak Indonesia akan menjadi negara yang berdaulat, yaitu mempersiapkan sebagai negara yang merdeka tanggal 17 Agustus 1945 sudah sangat disadari oleh para pendiri bangsa ini bahwa Indonesia sebagai negara yang bersifat keberagaman dalam keberagamaan. Karena itu segala kebijakannya selalu mempertimbangkan keberagaman tersebut sehingga dapat mengakomodir semua kepentingan yang ada. Seperti ditetapkannya Pancasila sebagai dasar negara oleh PPKI tanggal 18 Agustus 1945. Penetapan "Ketuhanan Yang Maha Esa" sebagai sila pertama dalam Pancasila adalah keputusan yang tepat dan berorientasi masa depan bangsa. Semua ini semata-mata untuk tetap menjaga keutuhan bangsa, karena keberagaman sangat sensitif untuk memicu konflik. Seperti dalam perumusan dasar negara kita yang dikenal dengan nama Pancasila, nilai-nilai yang tercantum dari sila pertama sampai kelima bersifat universal artinya dapat diterima oleh semua kalangan. Begitu juga dengan rumusan UUD 1945 khususnya pasal 29 yang mengakomodir kepentingan warganya untuk beribadat sesuai dengan agama dan kepercayaan yang dianutnya. Andaikatapun ada ketidaksetujuan terhadap kebijakan tersebut adalah masalah personal dan minoritas. Ini artinya negara menjamin kemerdekaan memeluk agama, 
sedangkan pemerintah berkewajiban melindungi penduduk dalam melaksanakan ajaran agama dan ibadat, sepanjang tidak bertentangan dengan peraturan perundang-undangan, tidak menyalahgunakan atau menodai, serta tidak mengganggu ketentraman umat dan ketertiban umum. Munculnya peristiwa-peristiwa sparatisme pasca kemerdekaan, awalnya bukanlah karena agama, tetapi lebih karena fakor ekonomi dan politik, kemudian barulah munculnya faktor agama yang ikut berkontribusi terhadap peristiwa sparatis tersebut.

Peranan pemerintah sangat penting dalam memberi bimbingan dan pelayanan agar setiap penduduk dalam melaksanakan ajaran agamanya dapat berlangsung dengan rukun, lancar dan tertib, baik yang bersifat internal maupun antar umat beragama. Untuk itu Mentri Agama dan Mentri Dalam Negeri mengeluarkan SKB No. 01/Ber/MDN-MAG/1969 tentang Pelaksanaan Tugas-Tugas Aparatur Pemerintah dalam Menjamin Ketertiban dan Kelancaran Pelaksanaan Pengembangan dan Ibadat Agama oleh Pemeluknya. Dan pada tanggal 21 Maret 2006 diterbitkan juga Peraturan Bersama Menteri Agama dan Menteri Dalam Negeri No.9 tahun 2006 dan No. 8 tahun 2006 tentang Pedoman Pelaksanaan Tugas Kepala Daerah dan Wakil Kepala daerah terkait dengan kerukunan umat beragama dan pendirian rumah ibadat. Pemahaman akan peraturan yang ada dan dilandasi oleh niat untuk bersatu berdasar pada nilai-nilai agama dan nilanilai kebudayaan yang dianutnya akan memunculkan rasa kebersamaan. Disamping kebijakan tersebut, mengusulkan perdamaian dapat dilakukan melalui pendidikan yang menggambarkan perdamaian antar agama, toleransi dan kejujuran sehingga mampu menciptakan komunikasi yang normal antar umat agama yang berbeda, mampu mengelola konflik dengan cara tidak kekerasan (Suseno, 2003, hal. 126-127). Dan akhirnya, dalam kondisi yang negara yang penuh dengan konflik SARA, khususnya konflik agama, sudah sepantasnya diperlukan "Agama Cinta".
Agama Cinta yang dimaksudkan bukanlah "agama baru". Agama Cinta adalah sebuah istilah yang menegaskan bahwa setiap agama, sebuah keyakinan akan Tuhan atau "Yang Tertinggi" selalu punya pesan dasar yang sama, "mengajarkan kebaikan dan Cinta" (Nurcholis \& M. Dja'far, 2014: 9). Dan (Ahmad, 2016: 176), merujuk Q.S. 44:13 mengamanatkan sebagai berikut:

"Hai manusia, sesungguhnya kami menciptakan kamu, dari seorang laki-laki dan seorang perempuan dan kami jadikan kamu berbangsa-bangsa, bersuku-suku agar supaya kamu saling kenal mengenal. Sesungguhnya orang yang paling mulia di antara kamu di hadirat Allah ialah orang yang paling bertaqwa di antara kamu. Sesungguhnya Allah Maha Mengetahui dan Maha Mengenal”

Dan Gandhi (Gandhi, 2016: 147-148) mengatakan;

"Jalan yang mulia adalah sikap yang bersahabat dengan seluruh dunia dan memandang seluruh umat manusia sebagai sanak saudara. Siapa saja yang membedabedakan penganut agama sendiri dengan agama lain berarti memberi pendidikan keliru kepada penganut agamanya sendiri dan membuka jalan untuk penghianatan agama"

\section{KESIMPULAN}

Pada prinsipnya tidak ada satupun agama dan kepercayaan yang dianut oleh umat manusia mengajarkan kekerasan, kebencian terhadap manusia dan makhluk hidup, yang ada adalah pemahaman yang salah terhadap ajaran agama yang dianutnya. Perbedaan suku, ras, agama merupakan keniscayaan terahadap cintaan-Nya, mengingkari pebedadaan tersebut, sama dengan mengingkari kodrat. Berdasarkan latar belakang sejarah, sejak kehadiran agama-agama di Indonesia, bumi Indonesia bukanlah kosong dari sistem kepercayaan, hanya saja bentuknya masih sangat sederhana. Kehadiran agama-agama tersebut 
menyempurnakan sistem kepercayaan yang ada melalui proses akulturasi. Sikap "empati" merupakan modalitas dan struktur, pola yang dimiliki oleh bangsa Indonesia, sehingga dalam menanggapi kehadiran berbagai agama tersebut tidak terjadi konflik. Para pendiri bangsa sebagai aktor/agen akhirnya menetapkan struktur, pola dalam kehidupan berbangsa dan bernegara yang sekaligus mengatur produsennya yang dikenal dengan empat konsensus bangsa yaitu; Pancasila, Undang-Undang Dasar Tahun 1945 (UUD 1945), Negara Kesatuan Republik Indonesia (NKRI), dan Kebhinekaan.

\section{DAFTAR RUJUKAN}

Abdila, M. 2003. Toleransi Beragama dalam Masyarakat Demokrasi dan Multikultural. (Dalam Konflik Komunal di Indonesia Saat Ini). Leiden: INIS.

Agger, B. 2014. Teori Sosial Kritis, Kritik, Penerapan dan Implikasinya. Yogyakarta: Kreasi Wacana.

Ahmad, R. 2016. Fatwa Hubungan Antaragama. Dalam R. Ahmad, Fatwa Hubungan Antaragama di Indonesia, Kajian Kritis Tentang Karakteristik, Praktik, dan Implikasinya (hal. 2-3). Jakarta: Gramedia.

Ali, A. 2008. Surga Bukan Monopoli Muslim. Tempo.

Anderson, B. 2016. Hidup di Luar Tempurung. Serpong: CV Marjin Kiri.

Anonim. 2005. Hindu Alukta. Dipetik Maret Senin, 2017 , dari http://hindualukta.blogspot.co.id/2016 /09/pengertian-catur-guru-danbagian.html.

Anonim. 2009. Prinsip-Peinsip Toleransi Antar Umat Agama. Dipetik Maret Senin, 2009, dari (http://www.pesantrenvirtual.com.
Arisandi, H. 2015. Buku Pintar Pemikiran TokohTokoh Sosiologi Dari Klasik sampai Modern . Yogyakarta: IRCiSoD.

Echikwomye, B. 2013. Security Challenges in Africa: The Role of International Community in Conflict Resolution in Nigeria. International Journal of African and Asia.

Gandhi, M. 2016. Semua Manusia Bersaudara. Jakarta: Yayasan Pustaka Obor.

Giddens, A. 2010. Teori Strukturasi, Dasar-Dasar Pembentukan Struktur Sosial Masyarakat. Yogyakarta: Pustaka Pelajar.

Jellen, T. 2007. The Constitutional Basis of Religious Pluralism in the United States: Causes and Consequences. ANNALS, AAPSS.

Lombard, D. 2005. Nusa Jawa: Silang Budaya 2. Jakarta: Gramedia.

Lubis, A. Y. 2014. Postmodernisme, Teori dan Metode. Depok: PT Rajagrafindo Persada.

Martono, N. 2014. Sosiologi Perubahan Sosial, Perspektif Klasik, Modern, Posmodern, dan Poskolonilal. Jakarta: PT RajaGrafindo Persada.

Munawar-Rachman, B. 2009. http://media.isnet. org/islam. Dipetik Nopember Sabtu, 2015, dari Mengembalikan Kerukunan Umat beragama.

Nurcholis, A., \& M. Dja'far, A. 2014. Agama Cinta. Jakarta: Kompas Gramedia.

Pruit, D., \& Rubin, J. 2011. Teori Konflik Sosial. Yogyakarta: Pustaka Pelajar.

Rahman, A., \& Kambali. 2013. Religious Tolerance in Malaysia: Problems and Challenges. Internasional Journal of Ismaic Challeneges.

Soekarno. 1965. Di Bawah Bendera Revolusi Djilid Pertama. Djakarta: Panitya di Bawah Bendera Revolusi. 
Subagya, R. 1981. Agama Asli Indonesia. Jakarta: Djaya Pirusa.

Suseno, F. M. 2003. Faktor-Faktor yang Mendasari Terjadinya Konflik Antara Kelompok Etnis dan Agama di Indonesia. Dalam F. M. Suseno, Konflik Komunal di Indonesia Saat Ini (hal. 126-127). Leiden: INIS.

Sutrisno. 2001. Humanisme, Krisis, Humanisasi. Jakarta: Yayasan Obor.

Sutrisno, T. 1996. Dimensi Pertahanan Keamanan dari Integrasi Nasional. Dalam Integrasi Nasional, Teori Masalah dan Srategi. Jakarta: Ghalia Indonesia. 